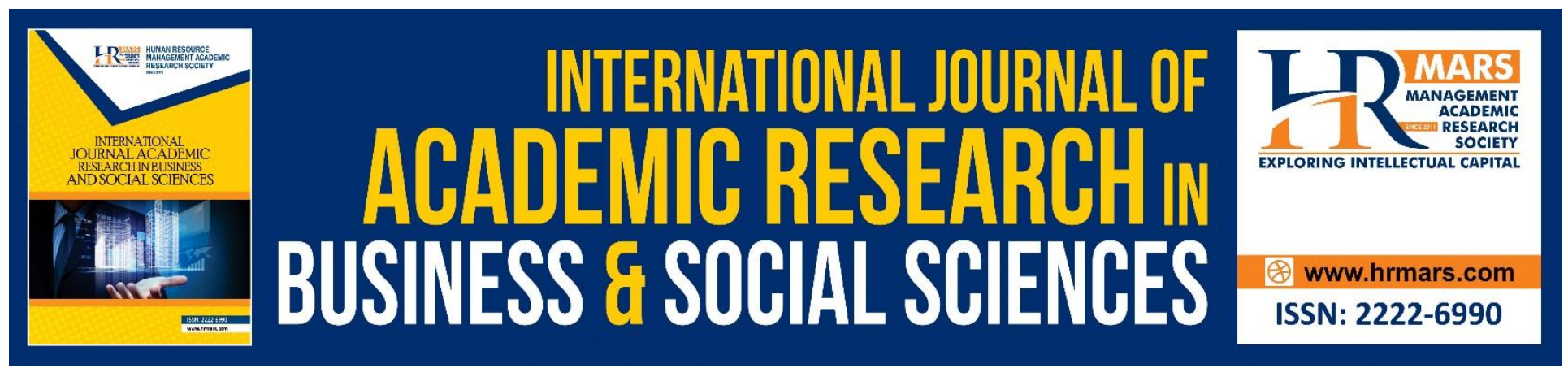

\title{
Study on the Perception of Lecturers from two Malaysian Universities on Integrated Cumulative Grade Point Average (iCGPA) Assessment
}

Jing Rui Tang, Earn Tzeh Tan, Ridzwan Che' Rus, Mohamed Nor Azhari Azman and Zaliza Hanapi

To Link this Article: http://dx.doi.org/10.6007/IJARBSS/v8-i7/4342

DOI: $\quad 10.6007 / I J A R B S S / v 8-i 7 / 4342$

Received: 24 June 2018, Revised: 22 July 2018, Accepted: 29 July 2018

Published Online: 05 August 2018

In-Text Citation: (Tang, Tan, Rus, Azman, \& Hanapi, 2018)

To Cite this Article: Tang, J. R., Tan, E. T., Rus, R. C., Azman, M. N. A., \& Hanapi, Z. (2018). Study on the Perception of Lecturers from two Malaysian Universities on Integrated Cumulative Grade Point Average (iCGPA) Assessment. International Journal of Academic Research in Business and Social Sciences, 8(7), 300-311.

Copyright: (c) 2018 The Author(s)

Published by Human Resource Management Academic Research Society (www.hrmars.com)

This article is published under the Creative Commons Attribution (CC BY 4.0) license. Anyone may reproduce, distribute, translate and create derivative works of this article (for both commercial and non-commercial purposes), subject to full attribution to the original publication and authors. The full terms of this license may be seen at: http://creativecommons.org/licences/by/4.0/legalcode

Vol. 8, No. 7, July 2018, Pg. 300 - 311

Full Terms \& Conditions of access and use can be found at http://hrmars.com/index.php/pages/detail/publication-ethics 


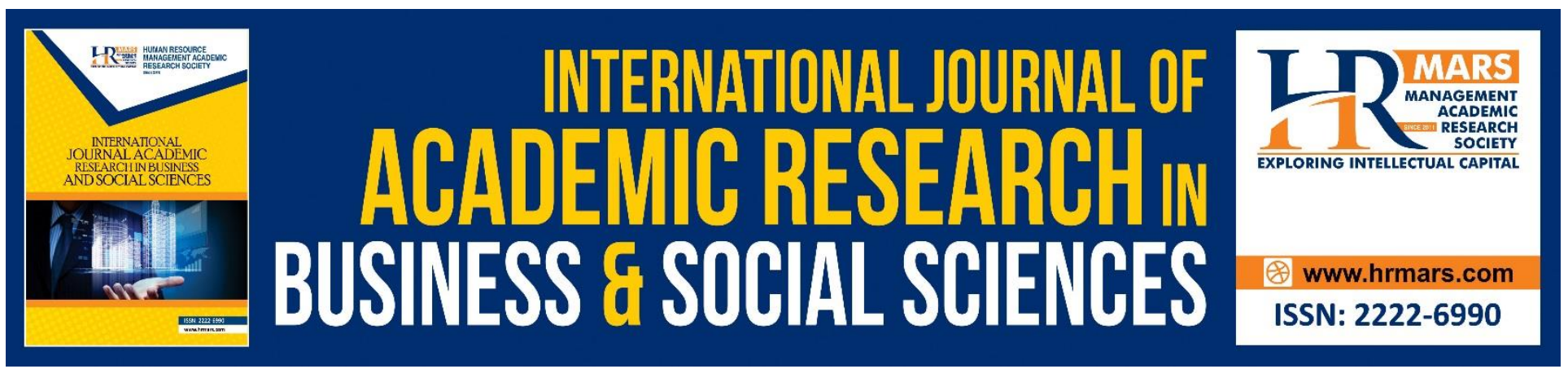

\title{
Study on the Perception of Lecturers from two Malaysian Universities on Integrated Cumulative Grade Point Average (iCGPA) Assessment
}

\author{
Jing Rui Tang1, Earn Tzeh Tan², Ridzwan Che' Rus ${ }^{1}$, Mohamed Nor \\ Azhari Azman ${ }^{1}$ and Zaliza Hanapi ${ }^{1}$ \\ Faculty of Technical and Vocational, Universiti Pendidikan Sultan Idris, Malaysia. \\ School of Electrical and Electronic Engineering, Universiti Sains Malaysia, Malaysia.
}

\begin{abstract}
Integrated Cumulative Grade Point Average (iCGPA) assessment is introduced in Malaysia in year 2015 as an assessment system to report the students' performance in knowledge together with attributes of ethics, leadership and entrepreneurship. The awareness, opinion, implementation and challenges regarding the iCGPA assessment of the lecturers from two faculties of two Malaysian universities were compared. A questionnaire of 29 items with five-point Likert-scale was developed as an instrument. IBM SPSS Statistics 20 was used for statistical analysis. Cronbach's alpha was used to measure internal consistency. Mann-Whitney $U$ test was performed to compare the differences between two independent groups via comparison of mean ranks. The awareness, opinion and implementation of iCGPA assessment by the lecturers from A University were significantly higher than those of the lecturers from B University, with p-values of $0.003,0.041$ and 0.006 , respectively. Lecturers from $A$ University felt that challenges faced by them were greater as compared to the lecturers from B University, but the difference was not statistically significant. Universities could organize workshops to distribute information about iCGPA assessment and arrange strategies to reduce lecturers' worries about the increment of workload resulting from the assessment.
\end{abstract}

Keywords: Assessment, Education, Holistic, Integrated Cumulative Grade Point Average, University Lecturers

\section{Introduction}

Education in the 21st century not only emphasizes achievement in the academic, but also covering a variety of contexts including beliefs, attitudes and value. The key to success in this 21 st century and the future employability is to combine both the hard and soft skills to fulfill the specific needs, such as the ability to think deeply about complex problems and apply creative solutions for problem solving (Maureen \& Yolanda, 2019). In a recent review on the relation between 21st century skills and digital skills, it is found that 21st century skills are wider than digital skills but they are not 
INTERNATIONAL JOURNAL OF ACADEMIC RESEARCH IN BUSINESS AND SOCIAL SCIENCES

Vol. 8, No. 7, July 2018, E-ISSN: 2222-6990 @ 2018 HRMARS

necessarily underpinned by information and communication technology. Seven core skills (i.e., technical, information management, communication, collaboration, creativity, critical thinking and problem solving) and five contextual skills (i.e., ethical awareness, cultural awareness, flexibility, selfdirection and lifelong learning) are identified (van Laar, van Deursen, van Dijk, \& de Haan, 2017).

Various studies have mentioned the importance of soft skills in higher education institutions, including in Thailand (Tang, 2018) and European countries (here refers to United Kingdom, Austria, Slovenia and Romania) (Andrews \& Higson, 2008). In Malaysia, the employment market seeks for competent candidates with soft skills. The Ministry of Higher Education has incorporated soft skills in the programs at universities by embedding them in the course syllabus and extracurricular activities (Mohd Adnan, Daud, Alias, \& Razali, 2017). Although a case study in Universiti Malaysia Sabah on the relationship between 200 trainees' soft skill attributes and employment status revealed that there is no significant relationship between the attributes (e.g., technical skills, communication skills, teamwork, leadership, professionalism and ethics) and the employment status (Nazron, Lim, \& Nga, 2017), the importance of soft skills is emphasized elsewhere (Shakir, 2009).

The first out of the ten shifts of the Malaysia Education Blueprint 2015-2025 (Higher Education) aims to produce graduates who are holistic, balanced and entrepreneurial. The Malaysia Education Blueprint 2015-2025 (Higher Education) serves as a guide to transform Malaysia's higher education system in order to produce holistic Malaysian youth with necessary values, knowledge and skills to face the challenges in this increasingly competitive and uncertain world. In light of the aim to produce holistic and balanced graduates, an appropriate assessment system is necessary to evaluate the graduates' holistic performance.

\section{Literature Review}

The Integrated Cumulative Grade Point Average (iCGPA) assessment (Ministry of Higher Education, 2016) is introduced in 2015 as an assessment system to report the students' learning gains in terms of their ethics together with the functional knowledge and technical abilities (Heng, 2015; Khor, 2015; Tay, 2015). This is in line with the aspiration to produce balanced and holistic graduates equipped with entrepreneurial mindsets. The assessment system could reflect the students' program learning outcome achievement for their entire study period as well as their holistic performance. A student's learning outcome of iCGPA attainment is illustrated in a radar chart known as the "spider web" with the eight Malaysian Qualifications Framework (MQF) Domains. These MQF domains are a) knowledge , b) psychomotor / practical / technical skills, c) social skills and responsibilities, d) values, attitude and professionalism, e) communication, leadership and team working skills, f) problem solving and scientific skills, g) information management skills and lifelong learning and h) managerial and entrepreneurial skills. Five public universities, namely Universiti Kebangsaan Malaysia, Universiti Malaysia Kelantan, Universiti Malaysia Pahang, Universiti Teknologi Mara and Universiti Malaysia Terengganu, became the pioneers to implement the iCGPA assessment in September 2015 (Khor, 2015). All public universities are expected to implement the iCGPA assessment in 2019.

There are nine program learning outcome domains as specified by the Ministry of Higher Education, including a) knowledge, b) practical skills, c) thinking and scientific skills, d) communication skills, e) social skills, teamwork and responsibility, f) values, ethics, morals and professionalism, g) information management and lifelong learning skills, h) managerial and entrepreneurial skills, and i) leadership 
INTERNATIONAL JOURNAL OF ACADEMIC RESEARCH IN BUSINESS AND SOCIAL SCIENCES Vol. 8, No. 7, July 2018, E-ISSN: 2222-6990 @ 2018 HRMARS

skills (Ministry of Education, 2015). The iCGPA assessment appeared to be a comprehensive measure of students' performance (Zubairu, Dauda, Paiko, \& Sakariyau, 2017). Findings based on the constructive alignment for Bachelor of Engineering (Hons.) Electrical Engineering program in Universiti Teknologi MARA reported that at least $2.4 \%$ of the total core courses should be included in the overall assessment to fulfill the requirement of $5 \%$ courses supporting attainment of the nine graduate attributes or learning outcomes (Yusof, Naim, Latip, Aminuddin, \& Ya'acob, 2017).

Ismail and Leow mentioned that iCGPA assessment system as an improved assessment system which assessed knowledge together with attributes of ethics, leadership and entrepreneurship should be acknowledged as an effort to ensure the quality of graduates (Ismail \& Leow, 2016). A study performed by Mohd Zahari et al. revealed that iCGPA assessment can identify the students' actual ability, knowledge, skills, and attitude. Meanwhile, the assessment helped to improve the students' performances and at the same time assisting the lecturers to diversify the teaching styles (Mohd Zahari, Hanafiah, \& Hemdi, 2017).

The iCGPA assessment is an important step in driving the practices of constructive alignment to evaluate the university students' performance as a whole. Since the introduction of the system is quite recent, limited works have been reported. Various factors could contribute to the success as well as the effectiveness of this new assessment system. As the key implementers of the system, lecturers in the universities play the lead roles in ensuring the success of the assessment. Yet, there is inadequate information available about university lecturers' perception with regard to this matter. Related studies mostly reported information or news about the introduction of the iCGPA assessment as well as findings about the practicality of the assessment as a holistic measure. Nonetheless, we believe that the university lecturers' perception directly or indirectly affect the success of the system. Findings from this study provide information about the university lecturers' perception about the iCGPA assessment that would help the policy maker in making decision for further improvement of the system. Furthermore, this study also highlights issues and concerns of university lecturers regarding the implementation of the system.

In this study, the awareness, opinion, implementation and challenges regarding the iCGPA assessment of the lecturers from two Malaysia universities, namely A and B Universities are investigated. University lecturers play a vital role in education (Lam, Hassan, Sulaiman, \& Kamarudin, 2018a, 2018b), here particularly the success of the implementation of iCGPA assessment. A questionnaire was developed and distributed to investigate the perception of the lecturers about the iCGPA assessment. This study also investigated if there are significant differences among the lecturers' perception from both the universities. It is hoped that findings of this study will better inform iCGPA assessment design and development towards better implementation of effective assessment practice.

\section{Methodology}

A questionnaire consisted of 29 items was developed as an instrument to investigate the awareness, opinion, implementation and challenges in the introduction of the iCGPA assessment system in two public universities in Malaysia (Chantaravisarut et al., 2018; Cramer et al., 2018; Fiene, Ireland, \& Brownlow, 2018). The first part retrieves respondents' background information, such as working experience as a university lecturer and highest education qualification. The remaining parts of the 
INTERNATIONAL JOURNAL OF ACADEMIC RESEARCH IN BUSINESS AND SOCIAL SCIENCES Vol. 8, No. 7, July 2018, E-ISSN: 2222-6990 @ 2018 HRMARS

questionnaire require information about the respondent's awareness, opinion, implementation and challenges regarding the implementation of the iCGPA assessment. The number of items is 10, 10, 4 and 5, respectively. The five-point Likert-scale is employed, where the score of 1 represents "Strongly disagree", 2 represents "Disagree", 3 for "Neither disagree nor agree", 4 for "Agree" and score of 5 indicates "Strongly agree".

IBM SPSS Statistics 20 is used for statistical analysis. This study aimed to investigate if there are statistically significant differences in terms of awareness, opinion, implementation and challenges in the implementation of the iCGPA assessment between the lecturers from A Faculty, A University and B Faculty, B University. The respondents' working experience as university lecturer and the highest education qualification are shown in Figures 1 and 2, respectively. In this study, the level of significance, ${ }^{\alpha}$, is defined as 0.05 (Gréa Krause, Beer-Borst, Sommerhalder, Hayoz, \& Abel, 2018; Koyama, Nakagawa, \& Tanaka, 2017).

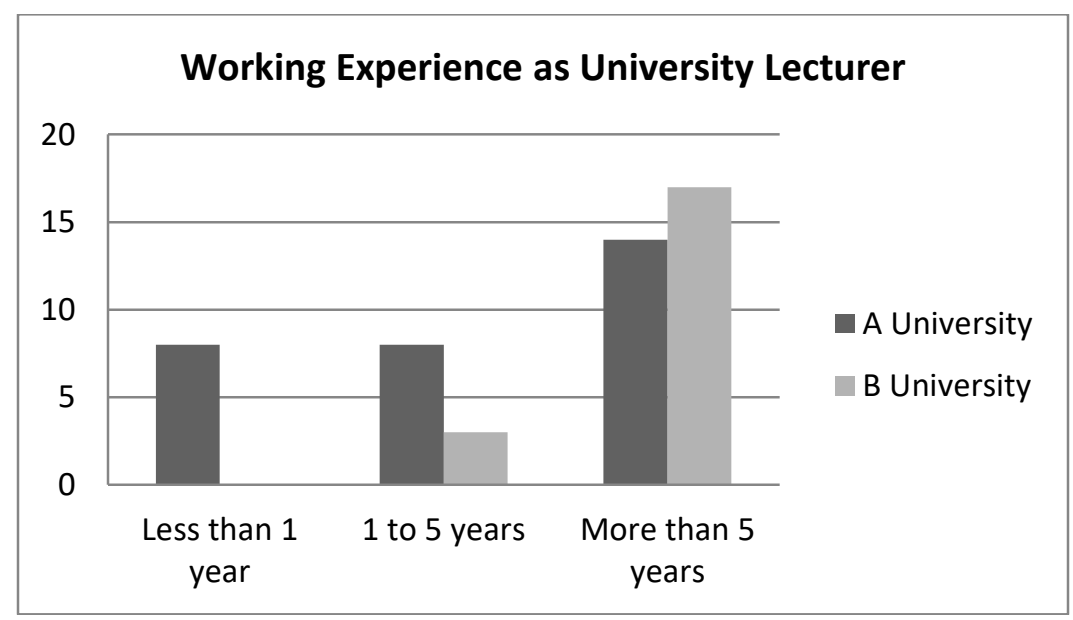

Figure 1. Respondents' working experience as university lecturer.

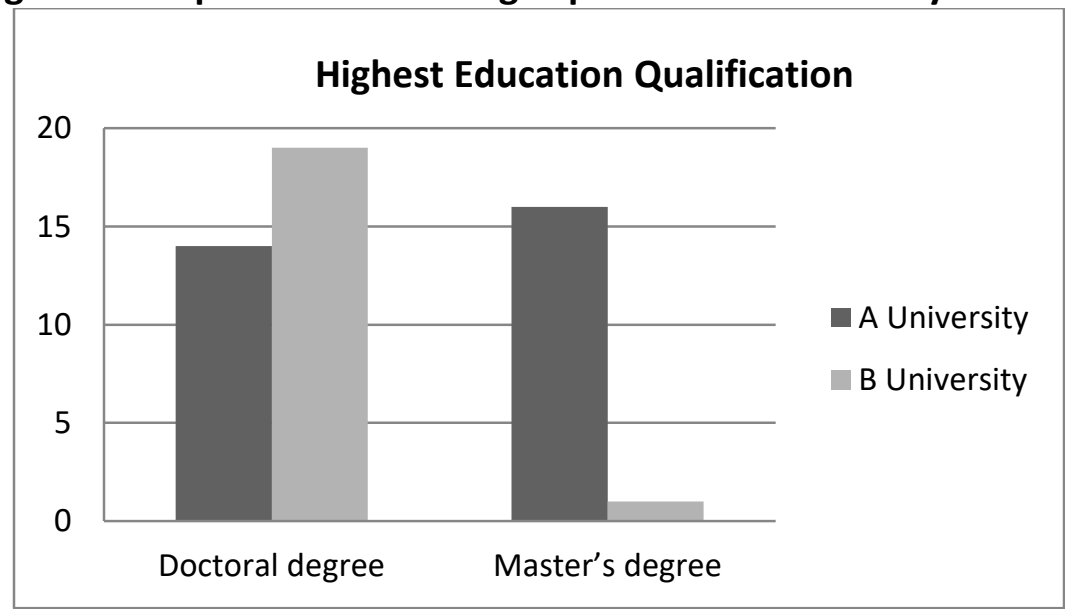

Figure 2. Respondents' highest education qualification.

\section{Result and Discussions}

A total of fifty lecturers participated in the survey. Thirty respondents come from A Faculty, A University and the remaining twenty are B Faculty, B University. The lecturers' minimum education qualification from both universities is Master's degree. Most of the respondents are lecturer with 
INTERNATIONAL JOURNAL OF ACADEMIC RESEARCH IN BUSINESS AND SOCIAL SCIENCES Vol. 8, No. 7, July 2018, E-ISSN: 2222-6990 @ 2018 HRMARS

more than five years working experience (i.e., 46.67\% for A University and 85\% for B University). The overall mean, standard deviation, minimum and maximum of scores for each part is demonstrated in Table 1.

Table 1. Mean, standard deviation, minimum and maximum of overall scores.

\begin{tabular}{ccccc}
\hline Part & Mean & $\begin{array}{c}\text { Standard } \\
\text { Deviation }\end{array}$ & Minimum & Maximum \\
\hline Awareness & 4.25 & 0.72 & 1.80 & 5.00 \\
Opinion & 4.03 & 0.62 & 2.50 & 5.00 \\
Implementation & 3.65 & 0.69 & 2.00 & 5.00 \\
Challenge & 3.09 & 0.76 & 1.60 & 5.00 \\
\hline
\end{tabular}

In order to measure the measure of internal consistency, Cronbach's alpha is used and the results are shown in Tables 2 and 3. The Cronbach's alpha is 0.937, which indicates an excellent level of internal consistency for the scale.

Table 2. Statistic of reliability measurement in overall.

\begin{tabular}{ccc}
\hline Cronbach's Alpha & $\begin{array}{c}\text { Cronbach's Alpha Based } \\
\text { on Standardized Items }\end{array}$ & Number of Items \\
\hline 0.937 & 0.943 & 29 \\
\hline
\end{tabular}

Table 3. Statistic of reliability measurement for every item.

\begin{tabular}{ccccc}
\hline Item & $\begin{array}{c}\text { Scale Mean if } \\
\text { Item Deleted }\end{array}$ & $\begin{array}{c}\text { Scale Variance } \\
\text { if Item Deleted }\end{array}$ & $\begin{array}{c}\text { Corrected Item } \\
\text { - Total } \\
\text { Correlation }\end{array}$ & $\begin{array}{c}\text { Cronbach's } \\
\text { Alpha if Item } \\
\text { Deleted }\end{array}$ \\
\hline Awareness & & & & \\
\cline { 1 - 3 } A1 & 108.420 & 234.657 & 0.462 & 0.936 \\
A2 & 109.100 & 231.031 & 0.405 & 0.937 \\
A3 & 108.580 & 230.330 & 0.535 & 0.935 \\
A4 & 108.640 & 229.500 & 0.595 & 0.935 \\
A5 & 108.600 & 225.959 & 0.751 & 0.933 \\
A6 & 108.640 & 225.051 & 0.732 & 0.933 \\
A7 & 108.580 & 225.310 & 0.773 & 0.933 \\
A8 & 108.620 & 223.955 & 0.769 & 0.933 \\
A9 & 108.620 & 225.261 & 0.739 & 0.933 \\
A10 & 108.680 & 223.691 & 0.755 & 0.933 \\
\hline Opinion & & & & \\
O1 & 108.680 & 230.957 & 0.606 & 0.935 \\
O2 & 108.780 & 229.767 & 0.650 & 0.934 \\
O3 & 108.960 & 225.672 & 0.716 & 0.933 \\
O4 & 108.860 & 227.143 & 0.649 & 0.934 \\
O5 & 108.820 & 232.110 & 0.588 & 0.935 \\
O6 & 108.880 & 229.822 & 0.651 & 0.934 \\
O7 & 108.820 & 231.742 & 0.605 & 0.935 \\
O8 & 108.920 & 227.912 & 0.665 & 0.934 \\
& & & &
\end{tabular}


INTERNATIONAL JOURNAL OF ACADEMIC RESEARCH IN BUSINESS AND SOCIAL SCIENCES Vol. 8, No. 7, July 2018, E-ISSN: 2222-6990 @ 2018 HRMARS

\begin{tabular}{ccccc} 
O9 & 109.000 & 228.980 & 0.647 & 0.934 \\
O10 & 108.940 & 229.323 & 0.715 & 0.934 \\
\hline Implementation & & & & \\
\cline { 1 - 1 } I1 & 109.420 & 229.718 & 0.444 & 0.937 \\
I2 & 109.060 & 228.180 & 0.638 & 0.934 \\
I3 & 108.780 & 228.216 & 0.694 & 0.934 \\
I4 & 109.740 & 228.523 & 0.50 & 0.936 \\
\hline Challenges & & & & \\
C1 & 109.360 & 226.562 & 0.565 & 0.935 \\
C2 & 109.920 & 237.871 & 0.213 & 0.940 \\
C3 & 109.900 & 235.724 & 0.260 & 0.939 \\
C4 & 109.960 & 239.509 & 0.148 & 0.941 \\
C5 & 109.920 & 232.157 & 0.429 & 0.937 \\
\hline
\end{tabular}

Mann-Whitney $U$ test is performed to compare the differences between two independent groups via comparison of mean ranks. Here, result of the Mann-Whitney $U$ test is demonstrated in Tables 4 and 5 .

Table 4. Rank table of Mann-Whitney U test.

\begin{tabular}{ccccc}
\hline Part & University & N & Mean Rank & Sum of Rank \\
\hline Awareness & A & 30 & 30.10 & 903.00 \\
& B & 20 & 18.60 & 372.00 \\
\hline Opinion & A & 30 & 28.43 & 853.00 \\
& B & 20 & 21.10 & 422.00 \\
\hline Implementation & A & 30 & 29.62 & 888.50 \\
& B & 20 & 19.33 & 386.50 \\
\hline Challenge & A & 30 & 26.07 & 782.00 \\
& B & 20 & 24.65 & 493.00 \\
\hline
\end{tabular}

Table 5. Results of Mann-Whitney U test.

\begin{tabular}{ccccc}
\hline & Awareness & Opinion & Implementation & Challenge \\
\hline Mann-Whitney U & 162.000 & 212.000 & 176.500 & 283.000 \\
Wilcoxon W & 372.000 & 422.000 & 386.500 & 493.000 \\
Z & -2.753 & -1.748 & -2.466 & -0.339 \\
Exact Sig. (2-tailed) & 0.003 & 0.041 & 0.006 & 0.370 \\
\hline
\end{tabular}

The awareness of the lecturers from A Faculty, A University is significantly higher than those of the lecturers from B Faculty, B University, with p-values of 0.003 . The awareness concerns about some details in the iCGPA assessment system, including the range of the achievement scale, the calculation process and also the domains of the MQF. The mean, standard deviation, minimum and maximum of every item in the category of awareness is demonstrated in Table 6 . It can be seen that the mean values for all the items obtained by the lecturers from A University are greater than those by $B$ University. Standard deviations of the data are generally large, with the range from 0.568 to 1.231. Although the maximum score for all the items by lecturers from both institutions are the same (i.e., 
INTERNATIONAL JOURNAL OF ACADEMIC RESEARCH IN BUSINESS AND SOCIAL SCIENCES

Vol. 8, No. 7, July 2018, E-ISSN: 2222-6990 @ 2018 HRMARS

5), majority of the minimum scores given by the lecturers from B University are lower. The data are more dispersed especially for items $A 5$ to A10, which are related to the MQF Domains.

Table 6. Mean, standard deviation, minimum and maximum of items under 'Awareness'.

\begin{tabular}{|c|c|c|c|c|c|c|c|c|}
\hline \multirow[t]{2}{*}{ Item } & \multicolumn{2}{|c|}{ Mean } & \multicolumn{2}{|c|}{$\begin{array}{l}\text { Standard } \\
\text { Deviation }\end{array}$} & \multicolumn{2}{|c|}{ Minimum } & \multicolumn{2}{|c|}{ Maximum } \\
\hline & $A$ & B & A & B & $A$ & B & $A$ & B \\
\hline $\mathrm{A} 1$ & 4.567 & 4.350 & 0.568 & 0.933 & 3 & 1 & 5 & 5 \\
\hline $\mathrm{A} 2$ & 4.067 & 3.400 & 0.907 & 1.231 & 2 & 1 & 5 & 5 \\
\hline $\mathrm{A} 3$ & 4.533 & 4.000 & 0.900 & 0.795 & 1 & 2 & 5 & 5 \\
\hline A4 & 4.400 & 4.050 & 0.968 & 0.605 & 1 & 3 & 5 & 5 \\
\hline A5 & 4.533 & 3.950 & 0.730 & 0.887 & 3 & 1 & 5 & 5 \\
\hline A6 & 4.500 & 3.900 & 0.777 & 0.968 & 3 & 1 & 5 & 5 \\
\hline A7 & 4.533 & 4.000 & 0.730 & 0.918 & 3 & 1 & 5 & 5 \\
\hline A8 & 4.567 & 3.850 & 0.728 & 0.988 & 3 & 1 & 5 & 5 \\
\hline A9 & 4.500 & 3.950 & 0.777 & 0.945 & 3 & 1 & 5 & 5 \\
\hline A10 & 4.533 & 3.750 & 0.730 & 1.020 & 3 & 1 & 5 & 5 \\
\hline
\end{tabular}

Regarding the opinion about iCGPA assessment, such as the importance of iCGPA assessment in reflecting the soft skills that are mastered by students, the introduction of the system could enhance curriculum delivery and assessment through constructive alignment, could match the graduates in fulfilling the needs of the industry and could increase the employment rate of graduates, the scores for the opinion of the lecturers from A Faculty, A University are significant higher than scores of the lecturers from B Faculty, B University (i.e., p-value equals 0.041). Based on Table 7 that tabulated the mean, standard deviation, minimum and maximum of items under 'Opinion', the mean values of the items are higher for the lecturers from A Faculty, while the standard deviations appeared to be similar for both institutions, with the range of 0.562 to 0.912 .

Table 7. Mean, standard deviation, minimum and maximum of items under 'Opinion'.

\begin{tabular}{|c|c|c|c|c|c|c|c|c|}
\hline \multirow[t]{2}{*}{ Item } & \multicolumn{2}{|c|}{ Mean } & \multicolumn{2}{|c|}{$\begin{array}{l}\text { Standard } \\
\text { Deviation }\end{array}$} & \multicolumn{2}{|c|}{ Minimum } & \multicolumn{2}{|c|}{ Maximum } \\
\hline & A & B & A & B & A & B & A & B \\
\hline 01 & 4.333 & 4.050 & 0.802 & 0.686 & 2 & 3 & 5 & 5 \\
\hline $\mathrm{O} 2$ & 4.200 & 4.000 & 0.887 & 0.562 & 2 & 3 & 5 & 5 \\
\hline $\mathrm{O} 3$ & 4.133 & 3.650 & 0.860 & 0.875 & 2 & 1 & 5 & 5 \\
\hline $\mathrm{O} 4$ & 4.133 & 3.900 & 0.900 & 0.912 & 2 & 1 & 5 & 5 \\
\hline 05 & 4.133 & 4.000 & 0.776 & 0.649 & 2 & 3 & 5 & 5 \\
\hline 06 & 4.033 & 4.000 & 0.850 & 0.649 & 2 & 3 & 5 & 5 \\
\hline 07 & 4.167 & 3.950 & 0.791 & 0.605 & 2 & 3 & 5 & 5 \\
\hline 08 & 4.133 & 3.750 & 0.819 & 0.851 & 2 & 1 & 5 & 5 \\
\hline 09 & 4.033 & 3.700 & 0.809 & 0.801 & 2 & 2 & 5 & 5 \\
\hline 010 & 4.133 & 3.700 & 0.681 & 0.733 & 3 & 2 & 5 & 5 \\
\hline
\end{tabular}


INTERNATIONAL JOURNAL OF ACADEMIC RESEARCH IN BUSINESS AND SOCIAL SCIENCES

Vol. 8, No. 7, July 2018, E-ISSN: 2222-6990 @ 2018 HRMARS

For the implementation of iCGPA assessment, a $\mathrm{p}$-value of 0.006 reveals that there are statistically significant differences in the scores between the lecturers from A Faculty, A University and from $B$ Faculty, B University. Items in this part include knowing the calculation process of iCGPA, whether the iCGPA Rubric Learning Outcomes Assessment Guide is a useful guide and also whether the lecturers receive sufficient information regarding the implementation of iCGPA assessment. Based on the mean, standard deviation, minimum and maximum values of items under 'Implementation' as tabulated in Table 8, similar to the scores in the previous parts (i.e., 'Awareness' and 'Opinion'), lecturers from A Faculty, A University gave higher scores for all the items. Lecturers from both the institutions gave the highest scores for item 13, which indicates that they agreed that to produce holistic, entrepreneurial and well-balanced graduates, it requires transformation and paradigm shift in the form of curriculum design, learning activities and tasks that are used for assessments. There are two items with the standard deviations of the scores greater for the lecturers from A Faculty, A University, which are items 12 and 14, corresponded to the usefulness of iCGPA Rubric Learning Outcomes Assessment Guide and whether the lecturers receive sufficient information regarding the implementation of iCGPA assessment. It can be seen from Table 8 that the standard deviation values for items 11 and 14 are larger as compared to items 12 and 13 for both the institutions, revealing that the responses varied a lot regarding whether the lecturers aware of the calculation process calculation process for a student's iCGPA achievement and also whether they receive sufficient information regarding the implementation of iCGPA assessment.

Table 8. Mean, standard deviation, minimum and maximum of items under 'Implementation'.

\begin{tabular}{|c|c|c|c|c|c|c|c|c|}
\hline \multirow[t]{2}{*}{ Item } & \multicolumn{2}{|c|}{ Mean } & \multicolumn{2}{|c|}{$\begin{array}{l}\text { Standard } \\
\text { Deviation }\end{array}$} & \multicolumn{2}{|c|}{ Minimum } & \multicolumn{2}{|c|}{ Maximum } \\
\hline & A & B & A & B & $A$ & B & A & B \\
\hline 11 & 3.600 & 3.300 & 0.932 & 1.302 & 2 & 1 & 5 & 5 \\
\hline 12 & 4.100 & 3.450 & 0.885 & 0.686 & 2 & 2 & 5 & 4 \\
\hline 13 & 4.367 & 3.750 & 0.765 & 0.716 & 3 & 2 & 5 & 5 \\
\hline 14 & 3.333 & 2.900 & 1.124 & 0.912 & 1 & 1 & 5 & 5 \\
\hline
\end{tabular}

In terms of the challenges in implementing the iCGPA assessment, lecturers from A Faculty, A University felt that challenges faced by them are generally greater as compared to the lecturers from B University, but the difference is not statistically significant (i.e., p-value equals 0.370). The standard deviations for all the items are large, with the highest values of 1.129 and 1.099 for lecturers from $A$ Faculty, A University and B Faculty, B University, respectively. This can be further verified by the large range of the minimum and maximum scores (i.e., mostly from 1 to 5 ). Items in this part are about the fairness in implementing the iCGPA assessment as well as the increment in workload and difficulty in developing the iCGPA assessment rubric. The mean scores for both the institutions range from 2.700 to 3.733, indicating that the responses varied from 'disagree' to 'agree'. Similar to the previous part (i.e., the 'Implementation'), the standard deviation values are generally large, with a minimum of 0.865 . This shows that the responses disperse widely from the minimum score of 1 to the maximum score of 5 frequently. 
INTERNATIONAL JOURNAL OF ACADEMIC RESEARCH IN BUSINESS AND SOCIAL SCIENCES Vol. 8, No. 7, July 2018, E-ISSN: 2222-6990 @ 2018 HRMARS

Table 9. Mean, standard deviation, minimum and maximum of items under 'Challenges'.

\begin{tabular}{|c|c|c|c|c|c|c|c|c|}
\hline \multirow[t]{2}{*}{ Item } & \multicolumn{2}{|c|}{ Mean } & \multicolumn{2}{|c|}{$\begin{array}{l}\text { Standard } \\
\text { Deviation }\end{array}$} & \multicolumn{2}{|c|}{ Minimum } & \multicolumn{2}{|c|}{ Maximum } \\
\hline & A & B & A & B & A & B & A & B \\
\hline $\mathrm{C} 1$ & 3.733 & 3.250 & 1.015 & 1.070 & 2 & 1 & 5 & 5 \\
\hline $\mathrm{C} 2$ & 3.000 & 2.950 & 0.983 & 1.099 & 1 & 1 & 5 & 5 \\
\hline $\mathrm{C} 3$ & 2.967 & 3.050 & 1.129 & 1.050 & 1 & 1 & 5 & 5 \\
\hline $\mathrm{C} 4$ & 2.800 & 3.150 & 1.095 & 1.040 & 1 & 1 & 5 & 5 \\
\hline $\mathrm{C} 5$ & 3.167 & 2.700 & 0.986 & 0.865 & 1 & 1 & 5 & 4 \\
\hline
\end{tabular}

In overall, this study performed Mann-Whitney $U$ test to investigate if there are statistically significant differences in terms of awareness, opinion, implementation and challenges in the implementation of the iCGPA assessment between the lecturers from A Faculty, A University and B Faculty, B University. The internal consistency for the scale is excellent, with the Cronbach's alpha value of 0.937. The mean ranks of the scores for all the four parts are higher for the lecturers from A Faculty, A University as compared to those from the B Faculty, B University. The only part that did not have significant difference between the two faculties is the 'Challenge', with a p-value of 0.370 . For the remaining three parts, namely 'Awareness', 'Opinion' and 'Implementation', the p-values are 0.003, 0.041 and 0.006 , respectively, indicating that there are statistically significant differences.

The iCGPA assessment as a relatively new assessment system acts as an important step in driving the practices of constructive alignment to evaluate the university students' holistic performance. Nonetheless, some lecturers might not be aware or alert regarding the details of the implementation of iCGPA assessment. The universities could organize workshop to distribute information about iCGPA assessment, especially about the calculation process as well as the development of the iCGPA assessment rubric. Furthermore, lecturers are concern regarding the increment in workload and working time with the implementation of iCGPA assessment. The universities could arrange strategies to reduce worries of lecturers such as providing sufficient time for lecturers to get familiar with the assessment system.

\section{Conclusions}

In accordance with the aim of the first shift of the Malaysia Education Blueprint 2015-2025 (Higher Education) to produce graduates who are holistic, balanced and entrepreneurial, the Integrated Cumulative Grade Point Average (iCGPA) assessment was introduced in 2015 as an assessment system to report the students' learning gains in terms of their ethics together with the functional knowledge and technical abilities. In this study, the awareness, opinion, implementation and challenges regarding the iCGPA assessment of the lecturers from A Faculty, A University and B Faculty, $B$ University are investigated. Mann-Whitney $U$ test shows that the mean ranks of the scores for all the four parts are higher for the lecturers from A University. The 'Awareness', 'Opinion' and 'Implementation' parts returned statistically significant differences for the comparison between two universities, with p-values of $0.003,0.041$ and 0.006 , respectively. The only part without significant difference is the 'Challenge'. Lecturers are the key agents in ensuring the success of this newlyintroduced assessment system. Thus, the universities could organize workshop to distribute information about iCGPA assessment since findings revealed that some lecturers were not highly 
INTERNATIONAL JOURNAL OF ACADEMIC RESEARCH IN BUSINESS AND SOCIAL SCIENCES Vol. 8, No. 7, July 2018, E-ISSN: 2222-6990 @ 2018 HRMARS

aware of the details such as the calculation of iCGPA. Also, strategies could be arranged to reduce worries of lecturers including the increment of workload resulting from the iCGPA assessment. Future work will involve more lecturers from various faculties as well as universities. The suggestions or feedbacks on iCGPA assessment from the lecturers should be taken into consideration for continuous improvement of the iCGPA assessment system. With the necessary precautions, issues arise from this newly introduced assessment system could be minimized and hence ensuring the assessment can achieve the desired outcome as a holistic measurement system.

\section{Funding}

This research was funded by the Geran Penyelidikan Khas Universiti Berteraskan Pendidikan 2017 by Universiti Pendidikan Sultan Idris entitled "Kajian Persepsi Pensyarah Fakulti Teknikal dan Vokasional Universiti Pendidikan Sultan Idris terhadap Penilaian Purata Nilai Gred Kumulatif Bersepadu (iCGPA)" with the research code of 2017-0322-107-01.

\section{Acknowledgement}

The authors would like to thank all the lecturers from the two faculties in the two Malaysian universities who participated in the survey.

\section{Corresponding Author}

Name: Jing Rui TANG

Affiliation: Faculty of Technical and Vocational, Universiti Pendidikan Sultan Idris, 35900 Perak, Malaysia.

Country: Malaysia

Email: tangjingrui@ftv.upsi.edu.my

\section{References}

Andrews, J., \& Higson, H. (2008). Graduate employability, 'soft skills' versus 'hard' business knowledge: A European study. Higher Education in Europe, 33(4), 411-422.

Chantaravisarut, N., Wirodwanich, T., Jessadapakorn, W., Sangsupawanich, P., Liabsuetrakul, T., \& Yuenyongviwat, A. (2018). Development and validation of the parent-reported drug hypersensitivity quality of life questionnaire. Journal of Allergy and Clinical Immunology, 141(2, Supplement), AB167.

Cramer, H., Lauche, R., Daubenmier, J., Mehling, W., Büssing, A., Saha, F. J., et al. (2018). Being aware of the painful body: Validation of the German Body Awareness Questionnaire and Body Responsiveness Questionnaire in patients with chronic pain. PLoS ONE, 13(2), e0193000.

Fiene, L., Ireland, M. J., \& Brownlow, C. (2018). The interoception sensory questionnaire (ISQ): A scale to measure interoceptive challenges in adults. [journal article]. Journal of Autism and Developmental Disorders.

Gréa Krause, C., Beer-Borst, S., Sommerhalder, K., Hayoz, S., \& Abel, T. (2018). A short food literacy questionnaire (SFLQ) for adults: Findings from a Swiss validation study. Appetite, 120, 275280.

Heng, W. A. (2015). ICGPA - Too little, too late? http://www.bfm.my/current-affairs-icgpa.html.

Ismail, N. H., \& Leow, C. S. (2016). The G.E.T. conceptual model: Teaching and learning environment for millennials. International Journal of Economics, Commerce and Management, IV(4), 591603. 
INTERNATIONAL JOURNAL OF ACADEMIC RESEARCH IN BUSINESS AND SOCIAL SCIENCES

Vol. 8, No. 7, July 2018, E-ISSN: 2222-6990 @ 2018 HRMARS

Khor, A. M. (2015). Towards an integrated grading system. The Star.

Koyama, S., Nakagawa, K., \& Tanaka, S. (2017). Transcranial direct current stimulation over the opercular somatosensory region does not influence experimentally induced pain: a triple blind, sham-controlled study. Neuroreport, 28(3), 158-162.

Lam, K. W., Hassan, A., Sulaiman, T., \& Kamarudin, N. (2018a). Evaluating the face and content validity of an instructional technology competency instrument for university lecturers in Malaysia. International Journal of Academic Research in Business and Social Sciences, 8(5), 367-385.

Lam, K. W., Hassan, A., Sulaiman, T., \& Kamarudin, N. (2018b). Instructional technology competencies as perceived by university lecturers in Malaysia. International Journal of Academic Research in Business and Social Sciences, 8(3), 401-417.

Maureen, N. S., \& Yolanda, K.-B. (2019). Essential skills for the 21st century workforce. In K. Jared \& B. Robert (Eds.), Handbook of Research on Promoting Higher-Order Skills and Global Competencies in Life and Work (pp. 134-147). Hershey, PA, USA: IGI Global.

Ministry of Education. (2015). Malaysia Education Blueprint 2015 - 2025.

Ministry of Higher Education. (2016). iCGPA Rubric Learning Outcomes Assessment Guide.

Mohd Adnan, Y., Daud, M. N., Alias, A., \& Razali, M. N. (2017). Importance of soft skills for graduates in the real estate programmes in Malaysia. Journal of Surveying, Construction and Property, $3(2)$.

Mohd Zahari, M. S., Hanafiah, M. H., \& Hemdi, M. A. (2017). ICGPA as an integrated grading system: A qualitative study. New Educational Review, 49(3), 167-175.

Nazron, M. A., Lim, B., \& Nga, J. L. H. (2017). Soft skills attributes and graduate employability: A case in Universiti Malaysia Sabah. Malaysian Journal of Business and Economics, 4(3).

Shakir, R. (2009). Soft skills at the Malaysian institutes of higher learning. Asia Pacific Education Review, 10(3), 309-315.

Tang, K. N. (2018). The importance of soft skills acquisition by teachers in higher education institutions. Kasetsart Journal of Social Sciences.

Tay, E. (2015, 10 August). Malaysia to roll out ICGPA programme. The Star. Retrieved from http://highered.easyuni.com/2015/08/malaysia-to-roll-ut-icgpa-programme/

van Laar, E., van Deursen, A. J. A. M., van Dijk, J. A. G. M., \& de Haan, J. (2017). The relation between 21st-century skills and digital skills: A systematic literature review. Computers in Human Behavior, 72, 577-588.

Yusof, A. L., Naim, N. F., Latip, M. F. A., Aminuddin, N., \& Ya'acob, N. (2017, 9-10 Nov. 2017). Implementation of integrated cumulative grade point average (iCGPA) towards academic excellence in Malaysia. Paper presented at the IEEE 9th International Conference on Engineering Education (ICEED).

Zubairu, U. M., Dauda, C. K., Paiko, I. I., \& Sakariyau, O. B. (2017). Religiosity and Moral Competence: A Study of Malaysia's Accounting Students. International Journal of Educational Research Review, 2(1), 1-14. 